DOI: https://doi.org/10.30525/978-9934-26-108-4-15

Stepan Lebedev

Senior Lecturer at Department of Higher Mathematics, Economical and Mathematical Methods

Simon Kuznets Kharkiv National University of Economics

\title{
DIGITAL TRANSFORMATION OF SOCIETY: BUSINESS MANAGEMENT BY HUMAN POTENTIAL DEVELOPMENT
}

\section{Summary}

The article examines educational technologies that are used for the formation and development of human potential with the aim of improving business management in modern conditions. The dual nature of learning as a system was taken into account. On the one hand, the growth of human potential determines the development of business. On the other hand, providing quality educational services is a business in itself. In the light of the concept of «LifeLong Learning», the analysis of the correlation between learning theories and technologies at such stages of human potential formation as Preparatory \& Secondary School - Higher Education Business Training was carried out. Particular attention was paid to the study of the role of digitalization in modern realities. The global network readiness NRI was considered as indicators of the level of digitalization of various countries. A comparative analysis of the level of development of digital technologies and its application in the education system at all stages of learning is carried out. These data were compared with the success of the economies of various countries as a consequence of the level of human potential development. Particular attention was paid to the issues of distance learning as a way to ensure the availability of education that is, the implementation of the «Education for All» policy. Examples of the use of various e-learning systems for online and offline training in the context of the COVID-19 pandemic are given.

\section{Introduction}

The modern stage of development of society is characterized as a postindustrial society based on knowledge. The term itself was proposed by the American economist Peter Drucker back in 1969, and it was actively used in their works by Gotthard Bechmann, Robert Lane, Fritz Machlup, Alvin Toffler and other philosophers, sociologists and economists. All of them emphasized the role of knowledge as a productive force. This concept was further developed in the works of the American sociologist Daniel Bell. It was Bell who developed the theory of post-industrial society, which he regarded not as a real-life society, but as a kind of analytical structure and a tool for theoretical analysis. In his fundamental work, he substantiated [1] that the 
transition to the post-industrial stage of development is a reflection of changes in the driving force of development not only of the economy, but also of society as a whole. This is the transition of a decisive role in the development of the economy from property or financial capital (industrial society) to knowledge, that is, to intellectual capital (post-industrial society). In addition, in the post-industrial society, most of the working population is employed in the service sector, and the number of people employed in industrial production and agriculture is constantly decreasing [2-4]. Such changes in the structure of employment occur as a result of an increase in labor productivity and a gradual transition to full automation of production as a result of the use of highly intelligent technologies. Employment is shifting to the service sector, and to machine technology is being replaced by intellectual and information technology.

The knowledge society is a form of organization in which scientific knowledge prevails, and therefore its existence is impossible without access to this knowledge, without the development of information technologies. The transition to a knowledge society is a global trend that simultaneously reflects society's needs for knowledge and the capabilities of modern information technologies to ensure the rapid dissemination of this knowledge and the availability of necessary information. It is the availability of information that is ensured thanks to the improvement of computer technic and the rapid development of global networks. In this sense, the state of modern society is also characterized as an information society. According to Manuel Castells [5; 6], the key concept of the information society is the "network», and the key characteristics of networks are that they are open and constantly evolving structures, to which the various «nodes» included in them. It is thanks to the development of information technologies and digitalization of information that the transition to the information society has become possible [7-10, etc.]. In turn, the formation of an information society is a condition for the transition to a knowledge society. Therefore, in many studies, the terms «knowledge society» and «information society» are used interchangeably.

From this brief overview, it follows that in modern conditions the success of the country's economy is largely determined by the level of human potential development, which constantly needs not only to be maintained, but also to be improved. In this regard, the policies «LifeLong Learning» [11; 12] and «Education for All» [13] have become one of the global trends. In order to master the streams of new rapidly changing information, it is necessary to constantly monitor this information and acquire new knowledge. Now Lifelong Learning is supported by a wide range of intergovernmental organizations, such as the Organization for Economic Co-operation and Development, the European Commission, the United Nations Educational, Social and Cultural Organization, the World Bank, and the International Labour Organization. The Education for All movement is a global commitment to provide quality basic education for all children, youth and 
adults. This movement was initiated by UNESCO, UNDP, UNFPA, UNICEF and the World Bank at the World Conference on Education for All in 1990 [14]. While these ideas are at first glance perceived as socially oriented, in fact they have a clear economic purpose. In fact, humanity can achieve sustainable development on the way to the formation of a knowledge society only through the synergy of such basic components: the information society, the knowledge-based economy, a learning society that implements Learning for All and LifeLong Learning.

The purpose of this work is a comparative analysis of the readiness of societies of different countries of the world for digital education, the implementation of which is one of the main components of the formation of human potential as a basic factor that determines the economy level of the post-industrial society. This readiness was considered at three successive levels of education: preparatory and secondary school, university and business education. At the same time, we have focused on distance learning technologies and tools in line with modern learning theories and the peculiarities of their implementation in a pandemic.

\section{Part 1. Readiness of various countries \\ to use information technologies and Ukraine's place in this rating}

Let us analyze the data obtained using the Networked Readiness Index (NRI), which reflects the level of readiness of various countries for the widespread use of information and communications technology (ICT) for the purposes of socioeconomic development. For the first time this index was published in 2002. Since then, it has been calculated annually by the international organization «World Economic Forum» together with the International Business School «INSEAD» [15]. It is compiled on the basis of publicly available statistics and the results of surveys of company executives. Initially, it consisted of three components: the environment offered by a given country for ICT (market, policy, regulatory and infrastructural environment); the readiness of the country's key stakeholders (individuals, businesses, and governments) to use ICT; the use of ICT by these stakeholders. Table 1 shows the results of measuring the NRI for the countries that make up the five leaders, as well as for Ukraine. These results were published in reports [15-17].

It should be noted that this table shows data only till 2016 inclusive, since soon the structure of the index has been revised, and it is possible to compare the new data with the data for the previous period only by the rank of the country.

NRI Index was evaluated for 121 countries, which were distributed by the level of income. Thus, 48 countries have high income, 37 countries have upper-middle income, 25 countries, including Ukraine, have lower-middle income, and 11 countries have low income. As you can see from Table 1, the composition of the leaders of the rating has changed little during the observed period, and for Ukraine there has been an increase in its place in this rating. 
Table 1

Networked Readiness Index dynamics

\begin{tabular}{|c|c|c|c|c|c|c|c|c|c|c|c|c|c|c|}
\hline \multirow[b]{2}{*}{ Country } & \multicolumn{2}{|c|}{2010} & \multicolumn{2}{|c|}{2011} & \multicolumn{2}{|c|}{2012} & \multicolumn{2}{|c|}{2013} & \multicolumn{2}{|c|}{2014} & \multicolumn{2}{|c|}{2015} & \multicolumn{2}{|c|}{2016} \\
\hline & 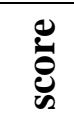 & 気 & 峁 & 氞 & 㫕 & 泀 & 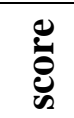 & 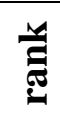 & 茪 & 跑 & 㫕 & 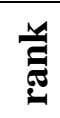 & 茪 & 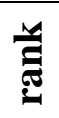 \\
\hline Sweden & 5.7 & 1 & 5.6 & 1 & 5.9 & 1 & 5.9 & 3 & 5.9 & 3 & 5.8 & 3 & 5.8 & 3 \\
\hline Singapore & 5.6 & 2 & 5.6 & 2 & 5.9 & 2 & 6.0 & 2 & 6.0 & 2 & 6.0 & 1 & 6.0 & 1 \\
\hline Denmark & 5.5 & 3 & 5.3 & 7 & 5.7 & 4 & 5.6 & 8 & 5.5 & 13 & 5.5 & 15 & 5.6 & 11 \\
\hline Switzerland & 5.5 & 4 & 5.3 & 4 & 5.6 & 5 & 5.7 & 6 & 5.6 & 6 & 5.7 & 6 & 5.8 & 7 \\
\hline United States & 5.7 & 5 & 5.3 & 5 & 5.6 & 8 & 5.6 & 9 & 5.6 & 7 & 5.6 & 7 & 5.8 & 5 \\
\hline Ukraine & 3.5 & 82 & 3.5 & 90 & 3.8 & 75 & 3.9 & 73 & 3.9 & 81 & 4.0 & 71 & 4.2 & 64 \\
\hline
\end{tabular}

Source: compiled based on data [15-17]

It should be emphasized that there is a direct correlation between the level of income in a country and its readiness to use digital technologies. Thus, the first 31st place in the ranking according to the value of NRI is occupied by countries with high income. This relationship is of a dual nature. On the one hand, a high NRI value indicates the ability to effectively use ICT in business development and, accordingly, receive high added value. On the other hand, a high level of income allows more and more funds to invest in the development of ICT, thereby increasing the readiness to use highly intelligent technologies in business, to create the intelligent high-tech enterprises. According to control theory, positive feedback reinforces the response of the system to a change in the input signal; therefore, it is used in engineering in situations where an acceleration of the response to a change in external parameters is required [e.g., 18]. Such a positive feedback provides the system with accelerated development in the direction given by external influence. Although this conclusion is based on the theory of control of technical systems, this statement is also true for systems of any nature, provided that all other influences are controllable. Accordingly, it can be expected that the economies of developed countries will develop at an even faster pace.

In recent years, interest in digital technologies has been steadily increasing. It has intensified even more in the context of the COVID-19 pandemic, when a significant part of the population of different countries was forced to go into self-isolation. In this regard, in 2019, it was decided to change the structure of the NRI, relying on twenty years of experience in comparative analysis of the digital economy. The index now maps the networked readiness landscape based on 62 indicators [19], which provides a comprehensive assessment of the digital readiness of countries. The Portulans Institute is considering this index for 130 countries. The structure of the updated index is shown in Figure 1.

According to the results of 2019, Ukraine took 67th rank with the score of 48.9, and in 2020 - 64th rank with the score of 48.4 [20], that is, it is still in the second half of the list. 


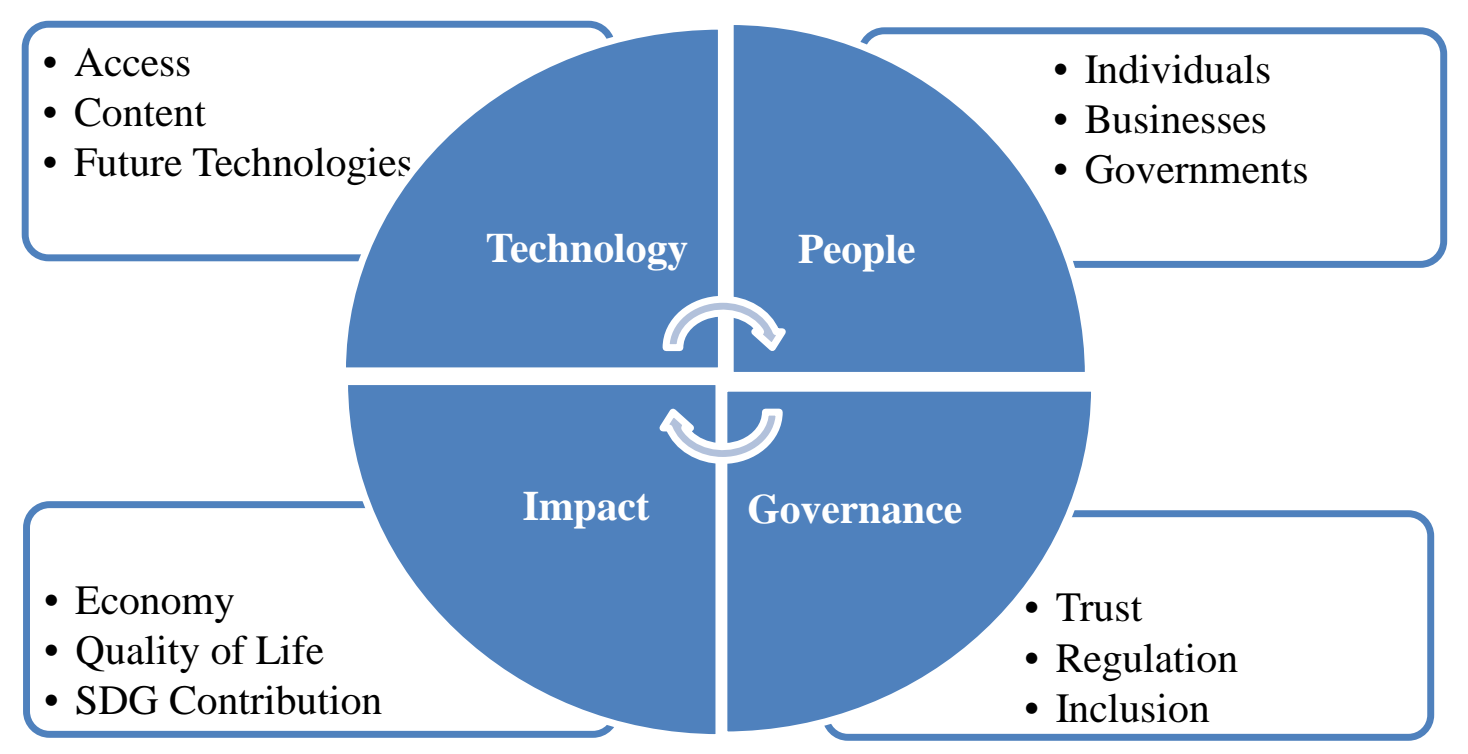

Figure 1. NRI structure since 2019

Let us consider in more detail the indicators of Ukraine over the past two years. The ranking positions for each of the four complex indicators for 2019 [19] are as follows: «Technology» - 71, «People» - 63, «Governance» - 67, «Impact»-65, and the overall result is 67th rank among 130 countries. Since the key issue in this work is the analysis of Ukraine's human potential and its contribution to economic development, we will dwell in more detail on the results of measuring the components of the «People» component. These data are presented in Table 2. As we can see from the above data, Ukraine ranks 1st (point 2.1.5) in the world in terms of adult literacy and 14th (point 2.1.4) in terms of enrollment in higher educational institutions. Thus, it can be argued that the population of Ukraine as a whole has a fairly high level of education. At the same time, Ukraine ranks 79th (point 2.3.4) in terms of the government spending on higher education. This means that a part of the population pays for tuition at universities on their own.

Another inconsistency should be noted. The level of education in Ukraine is high, but at the same time it takes only 80th place in terms of the level of connection of individuals to the Internet. This can be explained by the fact that the low level of income does not allow every resident to have a computer or other gadget, and also not in every area of our country it is possible to connect to the Internet. Since, as noted earlier, there is a positive inverse relationship between the NRI and a country's income, the gap between the economies of high-income countries and those of lower-middle-income countries can be expected to widen. That is, external influence (from the government) is needed to change this situation. 
Table 2

\section{Results of the NRI rating for Ukraine for the «People» component} (data of 2019)

\begin{tabular}{|l|c|c|}
\hline 1st sub-pillar: Individuals & rank & score \\
\hline 2.1.1 Internet users & 80 & 57.83 \\
\hline 2.1.2 Active mobile-broadband subscriptions & 97 & 19.87 \\
\hline 2.1.3 Use of virtual social networks & 92 & 37.83 \\
\hline 2.1.4 Tertiary enrolment & 14 & 60.28 \\
\hline 2.1.5 Adult literacy rate & 1 & 100.0 \\
\hline 2.1.6 ICT Skills & n/a & n/a \\
\hline 2nd sub-pillar: Businesses & & \\
\hline 2.2.1 Firms with website & 61 & 47.64 \\
\hline 2.2.2 Internet shopping & 49 & 27.80 \\
\hline 2.2.3 Professionals & 29 & 47.74 \\
\hline 2.2.4 Technicians and associate professionals & 45 & 48.57 \\
\hline 2.2.5 Extent of staff training & 67 & 36.05 \\
\hline 2.2.6 R\&D expenditure by businesses & 50 & 6.62 \\
\hline 3rd sub-pillar: Governments & & \\
\hline 2.3.1. Government online services & 90 & 52.30 \\
\hline 2.3.2 Publication and use of open data & 45 & 35.96 \\
\hline 2.3.3 ICT use and government efficiency & 65 & 42.01 \\
\hline 2.3.4 R\&D expenditure by governments and higher education & 79 & 16.04 \\
\hline
\end{tabular}

Source: based on data [19]

Here are some more data on the metrics that determine NRI score [19]. This is the «Impact» component, which belongs to the «Economy» sub-pillar and characterizes the impact of the level of ICT use on the state of the economy. So, according to point 4.1.1 «Medium and high-tech industry», which shows the proportion of medium and high-tech industry value added to total value added, Ukraine in 2016 ranked 48th with the score of 30.36\%, while for Singapore, which took 1st rank, this score was $78.13 \%$, and for Japan (6th rank) - 53.21\%. According to the point 4.1.2 «High-tech exports», the score of which is calculated as a percentage of the total export of industrial goods, in 2018 Ukraine took 71st rank (5.41\%), while for Singapore (3rd rank) this share amounted to 51.72\%, and for China (8th rank) - 30.89\%. Ukraine also lags significantly behind in number of applications filed under the Patent Cooperation Treaty (point 4.1.3). In the calculation of per million population, it is in 55th rank with the score of 3.42, while for Japan (1st rank) this score is 372.84, and for Sweden (2nd rank) - 346.57. All this has a significant impact on labor productivity. According to this indicator (point 4.1.4 «Labor productivity per employee»), which is calculated as labor productivity per person employed (USD at the exchange rate of 2018), in 2019 Ukraine took 81st rank with the score of 24715.03. For Singapore (2nd rank) this score was 153123.97, i.e., six times more. 
It should be noted that the NRI is not the only index used to determine the impact of digitalization on the level of economic development of a country. One of the most popular is the Digital Economy and Society Index (DESI), which summarizes the relevant indicators on the effectiveness of digital technology [21]. Although it is only used to assess the evolution of the EU countries in the area of digital competitiveness, it is useful to consider its structure.

The DESI index covers five main areas: Connectivity, Human capital, Use of internet, Integration of digital technology and Digital public services (eGovernment). Note that human capital is seen as one of the five key constituents of the DESI index. Let us take a closer look at this issue.

The human capital dimension of the DESI has two sub-dimensions covering namely 2a «Internet user skills» and $2 \mathrm{~b}$ «Advanced skills and development». The structure of these sub-dimensions and the scores of each element of these sub-dimensions, which were averaged over all the EU countries, are presented in Table 3.

Table 3

\section{Human capital indicators in DESI}

\begin{tabular}{|l|c|c|}
\hline \multicolumn{1}{|c|}{ Indicator } & $\mathbf{2 0 1 8}$ & $\mathbf{2 0 2 0}$ \\
\hline 2a.1. At least basic digital skills (\% individuals) & 57 & 58 \\
\hline 2a.2. Above basic digital skills (\% individuals) & 31 & 33 \\
\hline 2a.3. At least basic software skills (\% individuals) & 60 & 61 \\
\hline 2b.1. ICT specialists (\% total employment) & 3.7 & 3.9 \\
\hline 2b.2. Female ICT specialists (\% female employment) & 1.3 & 1.4 \\
\hline 2b.3. ICT graduates (\% graduates) & 3.5 & 3.6 \\
\hline
\end{tabular}

Source: based on data [22]

Note that among European countries Finland leads in both sub-dimensions of the «Human capital» component, followed by Sweden, Estonia and the Netherlands [21; 22]. Thus, the high scores of these countries as measured by the NRI correlate with those of the DESI index.

You should pay attention to point 2a.1. Although 85\% of European citizens already used the Internet in 2019, only 58\% of them had basic skills that enable people to participate in a digital society and consume digital goods. The survey has shown the top reasons for not having internet access at home such as the lack of need or interest (46\% of households without internet access in 2019), insufficient skills (44\%), high equipment costs (26\%) and cost barriers (24\%). That is, even in such prosperous countries there are quite a few people (almost 30\%) who have the opportunity to use the networks, but they do not have the knowledge and skills to fully realize this opportunity.

1. Digital technology and education. When considering the interpenetration of digital technologies and education, both researchers and practitioners usually focus on the use of digital technologies in the work of 
the teacher. And this has a foundation, because it is the combination of all the capabilities of information and communication technologies and their widespread use in the learning process that allows the teacher to fully convey the necessary information, and the student to perceive it correctly. However, this use of ICT, directed mainly from teacher to student, is a reflection of the theory of behaviorism in education. This theory became widespread at the beginning of the twentieth century thanks to the works of American psychologists Edward Lee Thorndike, John Broadus Watson, and Burrhus Frederic Skinner.

Currently, the most effective is the theory of programmed learning, which was proposed in the framework of behaviorism (the name speaks for itself), the author of which is Skinner. In accordance with this theory, the educational process is considered as teaching, i.e., knowledge is transferred from teacher to student in a finished form. Programmed learning provides that the teacher conveys information at lectures, and the student has the opportunity to implement feedback at seminars and practical classes. The use of ICT makes it possible, even when teaching in the classroom, to provide a better understanding between the teacher and students. And when working online or offline, it is the use of information and communication technologies that makes it possible to ensure the implementation of the educational process. This was manifested itself in the context of the COVID-19 pandemic. Such teaching method is still used in the vast majority of schools at all levels. Even in universities, it is widely used in teaching bachelors. And this is despite the fact that although this method makes it possible to obtain high-quality knowledge, it can no longer fully ensure the acquisition of skills that meet the requirements of a post-industrial society.

When considering the learning process, it is also necessary to take into account that ICT is not only a technology that facilitates learning, but in a post-industrial society these technologies are themselves the goal of learning. This is reflected in later learning theories. Another theory on which modern education is based is the theory of constructivism. In essence, it meets the requirements of the time more. This theory is based on the works of the Swiss psychologist and philosopher Jean William Fritz Piaget and was developed in the works of such scientists as Lev Vygotsky, Mikhail Bakhtin, Maria Montessori and others. Within the framework of this theory, it is believed that knowledge cannot be transferred to the student in a finished form. It is necessary to create conditions so that the student can successfully form his or her knowledge. In this case, the teacher determines the goal of the training, i.e., denotes the competencies that students must acquire in the learning process, and then guides them through the learning process. To concretize the information that students receive from the teacher only in general terms, they must use various resources, including Internet resources. After completing the assignment, students present their project, using various digital technologies for this. That is, learning based on the theory of constructivism helps not only 
to form deeper knowledge in the subject area and molds the student's skills for obtaining and systematizing them, but also teaches them to use the resources of the Internet to obtain information and forms the skills of using digital technologies at all stages of learning.

A further development of the theory of constructivism is the theory of connectivism [23; 24]. Discussion of this theory began in 2005, when one of its founders, George Siemens, presented this theory as a learning theory for the digital age [25]. This is truly a modern theory that meets the requirements for education in the 21st century. As an addition to the theory of constructivism, connectivism assumes that the teacher does not only formulate questions to which students must independently find answers. But he or she must help students integrate into the network community and get in touch with people who have the right information. According to this theory, knowledge is spread over an information network, from node to node, and is stored in various digital formats. For effective learning, a student must have two qualities: the ability to search and find the necessary information and the ability to filter the information found, highlighting the most important and necessary. In these conditions, the teacher should actively contribute to the creation of an infrastructure that allows his or her students to become part of the information community and actively use digital technologies for communication and learning.

The emergence of cognitive and socio-constructivist approaches in teaching has led to the fact that the main emphasis has shifted from the management of educational programs to monitoring how successfully students master these programs and how much they acquire the skills of independent search, analysis and synthesis of information, using network resources in this process. The open learning environment enables the learner to exercise freedom of learning. But at the same time, supporting students in this high-tech environment plays an important role in ensuring the effectiveness of learning, so it is critical to learning.

As we can see, the level of use of digital technologies in education and the direction of this use are largely determined by the framework of which theory of education the teaching is implemented. Similar conclusions can be found in the works of other researchers [26; 27, etc.]. Therefore, in order to assess the level of use in schools such educational technology as of information and communication technologies in general and digital technologies in particular, it is necessary to consider the extent to which these or other theories of education are applied at this stage of the development of society. Here are the results of some research. They are demonstrated in Figure 2. As we can see from the diagram, behaviorism is still the most widespread theory of teaching in modern schools. As the analysis of the data (Figure 2) shows, at present only $90.48 \%$ of schools use behaviorism to some extent. Moreover, $9.52 \%$ of them adhere to the theory of behaviorism in its purest form. Let me remind you that when implementing the theory of ICT behaviorism, only the tool for 
communicating information is used. This means that in most schools, students do not realize the opportunity to use intelligent learning technologies to the full extent that digital technologies allow. At the same time, only $20.04 \%$ of schools use elements of the theory of connectivism, which is considered the basis of education in the 21st century, and this theory is not yet used in its pure form.

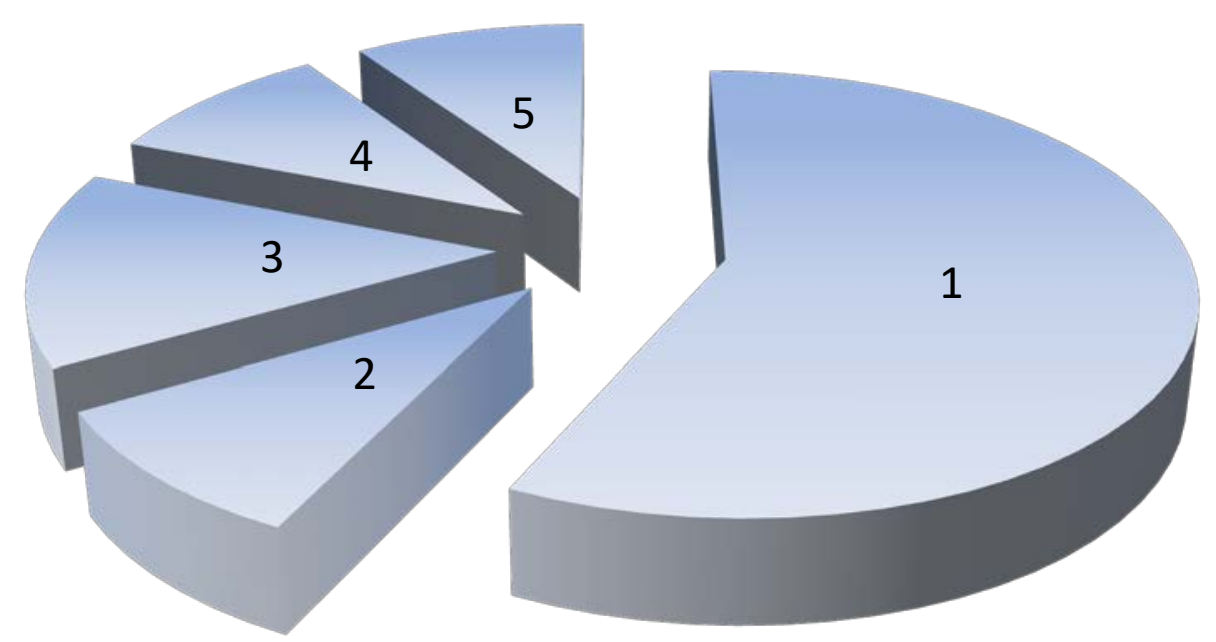

Figure 2. Proportion of the use of learning theories in schools

1. Behaviorism + Constructivism + Connectivism (57.14\%)

2. Behaviorism $(9.52 \%)$

3. Behaviorism + Constructivism (14.30\%)

4. Behaviorism + Connectivism (9.52\%)

5. Constructivism + Connectivism (9.52\%)

Source: based on data [26]

Everything that we have considered above has been related to the use of information and communication technologies in traditional school education at the primary and secondary school levels. Now let us move on to the analysis of the features of the use of ICT in higher education. Whereas learning in a regular school usually takes place in the classroom, in a higher school, distance learning can take place remotely. It can be done both offline and online. It should be noted that distance learning is also beginning to be practiced at the school. So, in Ukraine there are schools with online education that give a state certificate, for example, Planetaclub [28], and Optima [29]. Optima is the first distance learning school in Ukraine. To provide this form of learning, Optima uses such intellectual resources as 3D models, animations, educational games, case studies and much more. The quality of distance learning in this school can be assessed by the results of external independent testing. So, in 2020, Optima took 23rd place in the ranking of schools in Kyiv and 41st among the TOP-200 schools in Ukraine [30]. 
In universities, distance learning is one of the formats for providing education. In particular, classes with students of the part-time education are partially held in a distance form. If earlier the implementation of off-site education required lecturing in the classroom, and then students studied the material on their own using notes and textbooks, now such education can take place online and offline, that is, both in synchronous and asynchronous modes using various educational platforms. In this regard, information and communication technologies make it possible to eliminate temporal, spatial and quality barriers in the modern system of university education, which meets the requirements of a post-industrial society in terms of human potential formation. It is these capabilities of information technologies that make them indispensable for full-time education. If we turn to the theories of education, then it can be argued that modern universities have almost completely moved away from the methodology proposed in the framework of behaviorism. When teaching both bachelor's and master's degrees, they are widely used the methods provided by such educational theories as constructivism and connectivism.

As an illustration, we can cite the experience of teaching mathematical disciplines at Simon Kuznets Kharkiv National University of Economics (Ukraine). Let us first consider the structure of classroom studies for full-time students in the specialties of Economics, Management, and Marketing. In all compulsory disciplines, the time allotted for the study of each of them is 5 ECTS credits, i.e., 150 academic hours. The classroom time for subjects such as Higher Mathematics, Probability Theory and Mathematical Statistics, as well as Operations Research and Optimization Techniques, is divided by a ratio of 2/1/1. That is, half of the time is devoted to lectures, and the other half is equally divided between practical and laboratory studies. For a discipline such as Econometrics, the time allotted for classroom studies is divided between lectures and laboratory studies in a ratio of $1 / 1$.

Laboratory classes are held in the classrooms of the computing center of the S. Kuznets KhNUE. The laboratory study program assumes that the student independently performs calculations on a given topic, using software such as MathLab, Octave, MS Excel, or Statistica, and then presents these results, using mainly the capabilities of WS Word and Paint 3D.

The Moodle platform is used to guarantee all students of our university the open access to teaching materials and provide opportunity to carry out feedback. It is an electronic distance learning system [31], which allows to carry out such functions as the management of all types of education (electronic, full-time and part-time); checking the knowledge, abilities and skills acquired by students in the learning process; analysis of training and assessment of its results; provision of discipline content in any convenient format; formation and storage of an archive of educational materials.

Along with performing laboratory work, which is a reflection of the theory of constructivism, students are encouraged to complete a creative task. 
The meaning of this task is that students individually (outside the classroom) are invited to conduct an independent research and present its results in the form of a scientific article. And this is also an example of the embodiment of the provisions of the theory of constructivism in education. Similar teaching techniques are used when working with distance learning students.

As a result of the accumulated experience, two undoubted achievements should be noted. The first and most important achievement in the implementation of such an approach to teaching is that in a post-industrial society the using of modern teaching technologies and the formation of students' skills to use the possibilities of information resources to obtain, analyze and systematize knowledge helps them to improve their human potential as a future specialists. The second achievement, although it is technical, turned out to be key opportunity in the context of the COVID-19 pandemic. It consists in the fact that the experience, which was accumulated by the teaching staff of the S. Kuznets KhNUE during 10 years of using of a personal nurture system [32] made it possible to quickly set up the process of effective distance online learning.

It is worth paying attention to such an aspect of distance learning as the use of platforms for conducting online classes. Zoom, a cloud-based platform for video conferencing, webinars and other similar online events, was chosen as such a platform [33]. Like Moodle, Zoom has proven to be indispensable in a quarantine environment. However, the experience of remote work has shown that it is advisable to conduct video conferences when working in a classroom, for example, during laboratory classes. In the mode of such a conference, a student, asking a question, will have the opportunity to demonstrate his or her computer screen to all other students of the group, and other students can offer their own solution. In addition, the teacher, answering this question, will be able to show one of the solutions of the problem by showing all students the screen of his computer. Thus, the discussion is transferred to the group, and it is an effective teaching methodology within the framework of the provisions of both the theory of constructivism and the theory of connectivism.

Let us note one more feature related to distance learning. Since all classroom sessions were conducted at Zoom, i.e., in the video conference mode, it was possible to control not only the attendance of students, but also their activity. On this basis, students can be grouped into two groups. One of them includes those students who carefully attended classes that were held in the format of video conferences, and during the lesson took an active part in discussions, asked questions, and after the end of the lesson, they send to the website of the personal nurture system (PNS) the solution of the task intended for independent execution. In addition, such students frequently sought advice through both the PNS and e-mail. For students of this group, distance learning was more convenient because made it possible to communicate more closely with each other and with the teacher. Another group should include students 
who either often missed classes, or attended classes formally, without delving into the essence of the tasks and sending solutions with a great delay. Unfortunately, in distance learning, it is difficult for a teacher to motivate such students.

These two separate groups of students also showed themselves in the exam. As an example, consider the results of the exam in Probability Theory and Mathematical Statistics. Students passed this exam remotely through the PNS website. The exam was conducted on computers in real time. It should be noted that in the normal course of study, this exam is also conducted on a computer using the PNS, only in the classroom of the S. Kuznets KhNUE computing center. The exam results are shown in Figure 3.

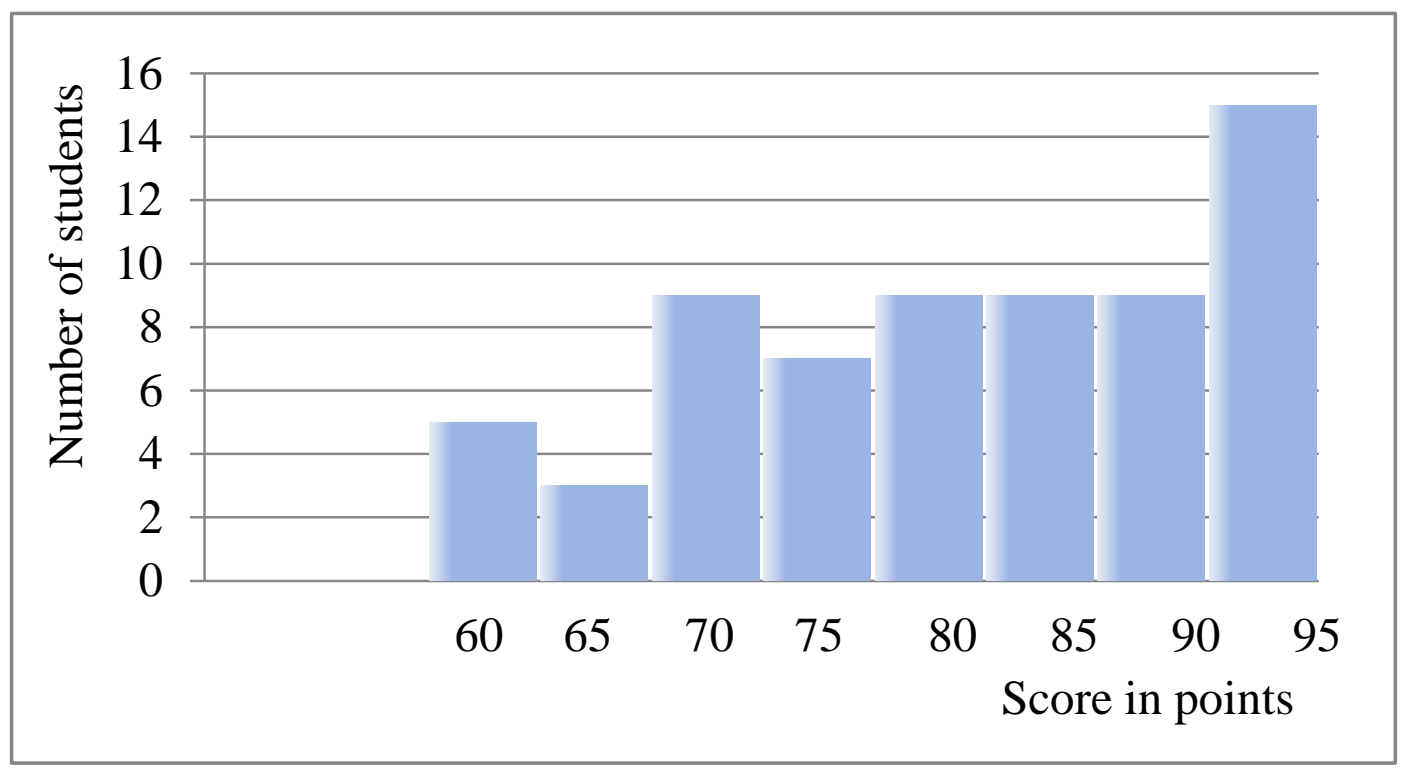

\section{Figure 3. Distribution of estimates obtained from the study} of Probability Theory and Mathematical Statistics

In the S. Kuznets KhNUE a cumulative assessment system is used. Out of 100 points, a student can receive a maximum of 60 points for work during a semester and 40 more points for an exam. These scores are then translated into ECTS grades and national grades. In accordance with the five-point national scale, $34.8 \%$ of the students who passed the exam received an Excellent grade, $36.2 \%$ - a Good grade and $29.0 \%$ - a Satisfactory grade. At the same time, those students who are classified in the last category, 67\% of students received a D grade, and the remaining 33\% received an E grade. Grades Excellent and Good were mainly obtained by students who actively worked in the semester, and those students who did not work well in the semester, but still managed to accumulate a passing score and get admission to the exam, received low marks on the exam or did not pass the exam at all. The conclusion suggests itself. All other things being equal, only those students who were able to motivate themselves, who understand the need to 
invest in themselves, increasing their human potential, are able to realize the opportunities for obtaining high-quality education provided by the use of information and communication technologies.

But this is the list of innovative methods used by the Department of Higher Mathematics and Economic and Mathematical Methods of S. Kuznets KhNUE is not limited. In the light of the concept of «LongLife Learning» the university provides the opportunity to receive postgraduate education. And you need to implement a completely different approach to teaching adults. Such students are already quite consciously investing in themselves, gaining knowledge and skills that they can capitalize in the foreseeable future in the literal sense. That is, they are ready to turn their accumulated human potential into human capital in the sector of the economy in which they work.

The work of a teacher not just with adults, but with people who have already realized themselves in the profession and want to achieve even more, requires the use of innovative teaching methods. And such techniques have been developed in our university. Already at the level of master's training programs, business games, simulations, trainings, and cases are actively used in teaching [34]. And some retraining programs are generally implemented in the format of business training or personal growth training [35]. And in such trainings there is a place for mathematics. An example is the author's training «Application of BSC-KPI» [36; 37].

The problem of developing a system of indicators for an objective and comprehensive assessment of business became relevant in the middle of the last century, when business from a large one became very large. American scientist, specialist in the field of management Peter Ferdinand Drucker was proposed an approach, which he himself called «Management by Objectives, or MBO» [38]. And at the end of the twentieth century, the American economist Robert S. Kaplan and the American business theorist David P. Norton modified the MBO method and supplemented it with the Balanced Scorecard, or BSC, as well as the key performance indicators, or KPI [39].

Recently, the use of Key Performance Indicators has attracted more and more interest as a measure of achieving a set goal when assessing the effectiveness of a business as a whole or its individual elements, as well as when assessing the effectiveness of using human potential. With the help of the KPI system, you can not only monitor and evaluate the effectiveness of the actions performed, but also build a remuneration system that will successfully motivate employees.

In accordance with the BSC methodology, the company's management must, first of all, highlight the areas of activity that are significant for the company as a whole, and determine for them a set of key indicators that must be regularly measured. When forming the KPI structure, it is necessary to clearly define the values of the indicators that must be achieved in the course of business activities. Moreover, it should be formulated in such a way that it is clear to both the performer and the specialist who controls the process. The 
motivation of each employee should be tied to the values of these indicators, and the results of their monitoring should be known to the performers. This allows participants to understand which business processes need to be improved, how to rationally allocate resources to achieve the company's strategic goals, and so on. Only in this case can the intended goal be achieved.

Such training allows not only to teach students to use the balanced scorecard in their practice, but also to independently develop key performance indicators for a comprehensive assessment of processes, to highlight critical paths that, ultimately, will determine the performance of the company as a whole. And the use of information and communication technologies makes it possible to provide open access to these indicators for all employees of the company, which will provide an opportunity to motivate them and direct their work, as well as form the feedback necessary in management.

\section{Conclusions}

The data presented in the work allow us to conclude that at the postindustrial stage of society's development, the main factor determining the development of the economy is human potential, and economic management involves knowledge management. In these conditions, the very process of forming knowledge, skills and abilities becomes the subject of business. Enterprises of the education system (schools, universities, training companies) sell their services, and the consumers of these services, purchasing them, invest money and time in the development of their personal human potential so that its subsequent capitalization would bring dividends. The success of an educational institution in the educational services market depends on how much this institution uses modern teaching methods in its practice. And since this is associated with the receipt, processing of a large amount of information and the subsequent embedding of new information into an already formed system of representations, the successful achievement of learning goals is impossible without the widespread use of information and communication technologies. It was the COVID-19 pandemic that accelerated the process of digitalization of society. Users began to more actively use the possibilities of network communication not only to solve everyday problems, but also to direct the resulting free time to self-development. In turn, the education system also improved its skills in the employment of ICT, which made it possible to provide quality education at all levels, from school to education and retraining of adults.

\section{References:}

1. Bell D. (1973) The coming of post-industrial society: A venture of social forecasting. New York: Basic books.

2. Inozemtsev V. L. (2000) Sovremennoe postindustrialnoe obshchestvo: priroda, protivorechiya, perspektivy [Modern post-industrial society: nature, contradictions, prospects]. Moscow: Logos. (in Russian) 
3. Buzgalin A. V., Kolganov A. I. (2003) Teoriya socialno-ehkonomicheskikh transformacij. Proshloe, nastoyashchee i budushchee ehkonomik «realnogo socializma» v globalnom postindustrialnom mire [The theory of socio-economic transformations (the last, the present and the future of the economies of «real socialism» in the global postindustrial world)]. Moscow: «Teis». (in Russian)

4. Orlov V. V., Gricenko V. S. (2012) Postindustrialnoe obshchestvo i problema truda [Post-industrial society and the problem of labor]. Filosofiya i obshchestvo, no. 3, pp. 60-78.

5. Castells M. (2000) The Information Age: Economy, Society and Culture. Vol. 1: The Rise of the Network Society. Oxford, England, and Cambridge, Massachusetts: Blackwell Publishers.

6. Castells M. (1996) The Rise of the Network Society. Cambridge, Mass: Blackwell Publishers.

7. Inozemtsev V. L. (2004) Informacionnoe obshchestvo [Information society]. Moscow: Aspekt Press. (in Russian)

8. Chernov A. (2003) Stanovlenie global'nogo informacionnogo obshchestva: problemy i perspektivy [Formation of the global information society: problems and prospects]. Moscow: Izdatelsko-torgovaya korporaciya «Dashkov i K». (in Russian)

9. Webster F. (2006) Theories of the Information Society. 3d ed. London and New York: Routledge.

10. Chuhno A. A. (2012) Vibrani praci [Selected works]. Kyiv: DNNU «Akad. fin. Upravlinnya». (in Ukrainian)

11. Communication from the commission. Making a European Area of Lifelong Learning a Reality. URL: https://www.europarl.europa.eu/meetdocs/committees/cult/ 20020122/com(2001)678_en.pdf (accessed 25 March 2021).

12. Field J. (2000) Lifelong learning and the new educational order. Stoke-on-Trent, England: Trentham Books.

13. Education for All (EFA). URL: https://unevoc.unesco.org/home/Education+For+All (accessed 25 March 2021).

14. Meeting Basic Learning Needs: A Vision for the 1990s. Background Document. World Conference on Education for All. Thailand 5-9 March 1990. URL: https://inee.org/ system/files/resources/The_Inter-agency_Commission_for_the_World_conference_on_ Education_for_All_1990_World_conference_on_EFA_1990_en.pdf (accessed 25 March 2021).

15. Networked Readiness Index (NRI). URL: https://digital.gov.ru/en/activity/ statistic/rating/indeks-gotovnosti-stran-k-setevomu-obshestvu/\#tabs|Compare:Place (accessed 25 March 2021).

16. The Global Information Technology Report 2015 ICTs for Inclusive Growth. URL: https://networkreadinessindex.org/2019/wp-content/uploads/pdf/2015_GITR_Full_ Report_final_with_NRI.pdf (accessed 25 March 2021).

17. The Networked Readiness Index 2016. URL: http://www3.weforum.org/ docs/GITR2016/WEF_GITR_Chapter1.1_2016.pdf (accessed 25 March 2021).

18. Polyakov K. Yu. (2012) Osnovy teorii avtomaticheskogo upravleniya [Foundations of the theory of automatic control]. Saint Petersburgh: Izd-vo SPbGMTU. (in Russian)

19. The Network Readiness Index 2019: Towards a Future-Ready Society. URL: $\quad$ https://www.insead.edu/sites/default/files/assets/dept/globalindices/docs/nri-2019.pdf (accessed 25 March 2021).

20. Network Readiness Index 2020: Digital Transformation at a Glance. URL: $\quad$ https://knoema.ru/infographics/ljisicg/network-readiness-index-2020-digitaltransformation-at-a-glance (accessed 25 March 2021).

21. Digital Economy and Society Index (DESI) 2020. URL: https://digitalstrategy.ec.europa.eu/en/library/digital-economy-and-society-index-desi-2020 (accessed 25 March 2021). 
22. Digital Economy and Society Index 2020. Thematic chapters. URL: $\quad$ https://eufordigital.eu/wp-content/uploads/2020/06/DESI2020ThematicchaptersFullEuropeanAnalysis.pdf (accessed 25 March 2021).

23. Downes S. What Connectivism Is Connectivism Conference: University of Manitoba. URL: http://tc.umanitoba.ca/moodle/mod/forum/discuss.php?d=12 (accessed 25 March 2021).

24. Boitshwarelo B. (2011) Proposing an integrated research framework for connectivism: Utilizing theoretical synergies. International Review of Research in Open and Distance Learning, no. 12(3), pp. 161-179.

25. George Siemens (2005) Connectivism: learning as network-creation. URL: http://masters.donntu.org/2010/fknt/lozovoi/library/article4.htm (accessed 25 March 2021).

26. Lowyck J. (2014) Bridging learning theories and technology-enhanced environments: a critical appraisal of its history. J.M. Spector et al. (eds.), New York; Springer Science+Business Media.

27. Altuna J., Lareki A. (2015) Analysis of the use of digital technologies in schools that implement different learning theories. Journal of Educational Computing Research, no. 53(2), pp. 205-227.

28. Navchalno-osvitnii tsentr onlain v Ukraini. URL: https://planetaclub.com.ua/uk (accessed 25 March 2021).

29. Centr obrazovaniya «OPTIMA». URL: https://optima.school/ru (accessed 25 March 2021).

30. Reitynh shkil Kyieva za rezultatamy ZNO 2020 roku. URL: https://ru.osvita.ua/ school/rating/76201/ (accessed 25 March 2021).

31. What is Moodle TM? The Comprehensive Moodle TM Learning Management System (LMS) Guide. URL: https://ethinkeducation.com/what-is-moodle-guide/ (accessed 25 March 2021).

32. Site of PNS of S. Kuznets KhNUE. URL: https://pns.hneu.edu.ua/?lang=en (accessed 25 March 2021).

33. The Zoom Platform. URL: https://marketplace.zoom.us/docs/guides/gettingstarted/zoom-platform (accessed 25 March 2021).

34. Serdiukov K. H. (2012) Intelektualnyi kapital pidpryiemstva yav obiekt otsinky [Intellectual capital of the enterprise as an object of evaluation]. Kharkiv: Vyd. KhNEU. (in Ukrainian)

35. Afanasiev M.V. (ed.) (2018) Treninhove navchannia v zakladi vyshchoi osvity [Training in a higher education institution]. Kharkiv: KhNEU im. S. Kuznetsia. (in Ukrainian)

36. Lebediev S. S. (2012) Treninh iz zastosuvanniam BSC-KPI yak skladova kompleksnoho treninhu $\mathrm{z}$ pidhotovky mahistriv za fakhom «Ekonomika i pidpryiemnytstvo». Zastosuvannia innovatsiinykh tekhnolohii u pidhotovtsi fakhivtsiv z ekonomiky, finansiv ta prava. Materialy Mizhnarodnoi naukovo- praktychnoi konferentsii. Vinnytsia : TOV «Nilan-LTD».

37. Lebediev S. S., Khvostenko V. S. (2019) Naukovyi tvir «Treninh: Zbalansovana systema pokaznykiv v otsiniuvanni kapitalizatsii liudskoho kapitalu». Svidotstvo pro reiestratsiiu avtorskoho prava na tvir № 85760 vid 13.02.2019. Avtorske pravo i sumizhni prava. Ofitsiinyi biuleten, no. 52, pp. 701.

38. Drucker P. F. (1999) Management challenges for the 21st century. New York: Harper Business.

39. Kaplan R.S., Norton D.P. (1996) The Balanced Scorecard: Translating strategy into action. Boston, MA: Harvard Business School Press. 